\title{
Front Matter: Volume 10221
}

, "Front Matter: Volume 10221," Proc. SPIE 10221, Mobile Multimedia/Image Processing, Security, and Applications 2017, 1022101 (10 May 2017); doi: 10.1117/12.2280898

SPIE Event: SPIE Commercial + Scientific Sensing and Imaging, 2017, Anaheim, SPIE. CA, United States 


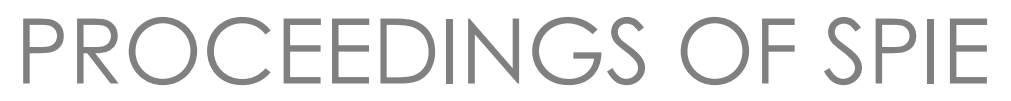

\section{Mobile Multimedia/lmage Processing, Security, and Applications 2017}

Sos S. Agaian

Sabah A. Jassim

Stephen P. DelMarco

Vijayan K. Asari

Editors

10-11 April 2017

Anaheim, California, United States

Sponsored and Published by

SPIE 
The papers in this volume were part of the technical conference cited on the cover and title page. Papers were selected and subject to review by the editors and conference program committee. Some conference presentations may not be available for publication. Additional papers and presentation recordings may be available online in the SPIE Digital Library at SPIEDigitallibrary.org.

The papers reflect the work and thoughts of the authors and are published herein as submitted. The publisher is not responsible for the validity of the information or for any outcomes resulting from reliance thereon.

Please use the following format to cite material from these proceedings:

Author(s), "Title of Paper," in Mobile Multimedia/lmage Processing, Security, and Applications 2017, edited by Sos S. Agaian, Sabah A. Jassim, Stephen P. DelMarco, Vijayan K. Asari, Proceedings of SPIE Vol. 10221 (SPIE, Bellingham, WA, 2017) Seven-digit Article CID Number.

ISSN: 0277-786X

ISSN: 1996-756X (electronic)

ISBN: 9781510609433

ISBN: 9781510609440 (electronic)

Published by

SPIE

P.O. Box 10, Bellingham, Washington 98227-0010 USA

Telephone +1 3606763290 (Pacific Time) · Fax +1 3606471445

SPIE.org

Copyright (c) 2017, Society of Photo-Optical Instrumentation Engineers.

Copying of material in this book for internal or personal use, or for the internal or personal use of specific clients, beyond the fair use provisions granted by the U.S. Copyright Law is authorized by SPIE subject to payment of copying fees. The Transactional Reporting Service base fee for this volume is $\$ 18.00$ per article (or portion thereof), which should be paid directly to the Copyright Clearance Center (CCC), 222 Rosewood Drive, Danvers, MA 01923. Payment may also be made electronically through CCC Online at copyright.com. Other copying for republication, resale, advertising or promotion, or any form of systematic or multiple reproduction of any material in this book is prohibited except with permission in writing from the publisher. The CCC fee code is 0277-786X/17/\$18.00.

Printed in the United States of America.

Publication of record for individual papers is online in the SPIE Digital Library.

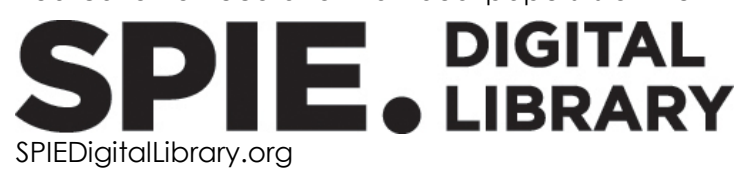

Paper Numbering: Proceedings of SPIE follow an e-First publication model. A unique citation identifier (CID) number is assigned to each article at the time of publication. Utilization of CIDs allows articles to be fully citable as soon as they are published online, and connects the same identifier to all online and print versions of the publication. SPIE uses a seven-digit CID article numbering system structured as follows:

- The first five digits correspond to the SPIE volume number.

- The last two digits indicate publication order within the volume using a Base 36 numbering system employing both numerals and letters. These two-number sets start with 00, 01, 02, 03, 04, 05, 06, 07, 08, 09, OA, OB ... 0Z, followed by 10-1Z, 20-2Z, etc. The CID Number appears on each page of the manuscript. 


\title{
Contents
}

\author{
$\checkmark$ Authors \\ vii Conference Committee
}

SESSION 1 AUDIO-VISUAL HUMAN IDENTIFICATION

1022102 State-space based modeling for imaging system identification [10221-1]

1022105 Fast and accurate face recognition based on image compression [10221-4]

1022106 Autonomous facial recognition system inspired by human visual system based logarithmical image visualization technique [10221-5]

1022107 Pattern recognition algorithm using descriptors combined radio and visible spectra [10221-6]

\section{SESSION 2 IMAGE SEGMENTATION IN APPLICATIONS}

1022108 Automatic pelvis segmentation from x-ray images of a mouse model [10221-8]

1022109 Computer aided solution for segmenting the neuron line in hippocampal microscope images [10221-9]

10221 OA Medical image segmentation using 3D MRI data [10221-10]

$10221 \mathrm{OB} \quad$ Using trainable segmentation and watershed transform for identifying unilocular and multilocular cysts from ultrasound images of ovarian tumour [10221-11]

\section{SESSION 3 EVENT AND VISUAL OBJECTS DETECTION}

10221 OC Detection of chaotic dynamics in human gait signals from mobile devices (Invited Paper) [10221-12]

10221 OD 3D indoor scene reconstruction and change detection for robotic sensing and navigation [10221-13]

10221 OE Visible spectrum-based non-contact HRV and dPTT for stress detection (Invited Paper) [10221-14]

$10221 \mathrm{OF} \quad$ An automated technique for potential differentiation of ovarian mature teratomas from other benign tumours using neural networks classification of 2D ultrasound static images: a pilot study [10221-15] 
102210 Topological image texture analysis for quality assessment (Invited Paper) [10221-18]

$102210 \mathrm{~J}$ Key exchange using biometric identity based encryption for sharing encrypted data in cloud environment [10221-19]

POSTER SESSION

$10221 \mathrm{OL} \quad$ Forensic print extraction using 3D technology and its processing [10221-7]

$102210 \mathrm{M}$ Comparative study of palm print authentication system using geometric features [10221-21]

$102210 N \quad$ A novel method for rotation invariant palm print image stitching [10221-22]

$1022100 \quad$ Method for stitching microbial images using a neural network [10221-23]

$102210 Q$ A human visual based binarization technique for histological images [10221-25]

10221 OS Application of local binary pattern and human visual Fibonacci texture features for classification different medical images [10221-27] 


\section{Authors}

Numbers in the index correspond to the last two digits of the seven-digit citation identifier (CID) article numbering system used in Proceedings of SPIE. The first five digits reflect the volume number. Base 36 numbering is employed for the last two digits and indicates the order of articles within the volume. Numbers start with 00, 01, 02, 03, 04, 05, 06, 07, 08, 09, OA, OB...0Z, followed by 10-1Z, 20-2Z, etc.

Agaian, Sos S., 06, OA, OL, OM, ON, OQ, OS

Al Okashi, Omar M., 08

Al-Assam, Hisham, 08, 09, OB, OF, 0J

Albaidhani, Tahseen, 09

Al-karawi, Dhurgham, OF

Asaad, Aras T., Ol

Asari, Vijayan K., OD

Blasch, Erik, 05

Bourne, T., OF

Cen, Yigang, $\mathrm{OA}$

DelMarco, Stephen, OC

Deng, Yunbin, $O C$

Du, Hongbo, 08, OB, OF

Hassan, Waleed K., OJ

Hixson, Jonathan G., 02

Hutchinson, J. Andrew, OE

Ibrahim, Dheyaa Ahmed, OB

Ikonomidou, Vasiliki N., OE

Jassim, Sabah A., 09, OB, OF, OI

Kamath K. M., Shreyas, OL, OM, OQ

Kaur, Balvinder, 02, OE

Kazaryan, M. L., 07

Liu, Ruixu, OD

Marchuk, V. I., 0A, 00

Page, N., OF

Panetta, Karen, 06, OL, OM, ON, OQ

Rajeev, Srijith, OL, OM

Rajendran, Rahul, $\mathrm{OQ}$

Rao, Shishir Paramathma, ON

Rashid, Rasber Dh., Ol

Richter, A. A., 07

Sanghavi, Foram, OS

Sayasneh, A., OF

Semenishchev, E. A., 0A, 00

Shakhramanyan, M. A., 07

Timmerman, D., OF

Tolstova, I. V., 00

Voronin, V. V., 07, 0A, 00

Wan, Qianwen, 06

Zheng, Yufeng, 05 
Proc. of SPIE Vol. 10221 1022101-6

Downloaded From: https://www.spiedigitallibrary.org/conference-proceedings-of-spie on 26 Apr 2023 Terms of Use: https://www.spiedigitallibrary.org/terms-of-use 


\section{Conference Committee}

Symposium Chair

Majid Rabbani, Rochester Institute of Technology (United States)

Symposium Co-chair

Robert Fiete, Harris Corporation (United States)

Conference Chairs

Sos S. Agaian, The University of Texas at San Antonio (United States)

Sabah A. Jassim, The University of Buckingham (United Kingdom)

Conference Co-chairs

Stephen P. DelMarco, BAE Systems (United States)

Vijayan K. Asari, University of Dayton (United States)

Conference Program Committee

David Akopian, The University of Texas at San Antonio (United States)

Cesar Bandera, BanDeMar Networks (United States)

Chang Wen Chen, University at Buffalo (United States)

Reiner Creutzburg, Fachhochschule Brandenburg (Germany)

Eliza Yingzi Du, Qualcomm Inc. (United States)

Frederic Dufaux, Telecom ParisTech (France)

Touradj Ebrahimi, Ecole Polytechnique Fédérale de Lausanne (Switzerland)

Erlan H. Feria, College of Staten Island (United States)

Artyom M. Grigoryan, The University of Texas at San Antonio (United States)

Phalguni Gupta, Indian Institute of Technology Kanpur (India)

Jonathan G. Hixson, U.S. Army Night Vision \& Electronic Sensors

Directorate (United States)

Yo-Ping Huang, National Taipei University of Technology

(Taiwan, China)

Balvinder Kaur, U.S. Army Research, Development and Engineering

Command (United States)

Jacques Koreman, Norwegian University of Science and Technology (Norway)

Maryline Maknavicius, TELECOM \& Management SudParis (France)

Alessandro Neri, Università degli Studi di Roma Tre (Italy) 
Cheryl L. Resch, Johns Hopkins University Applied Physics Laboratory (United States)

Haleh Safavi, NASA Goddard Space Flight Center (United States)

Harin Sellahewa, The University of Buckingham (United Kingdom)

Yuri Shukuryan, National Academy of Sciences of Armenia (Armenia)

Viacheslav Voronin, Don State Technical University

(Russian Federation)

Yue Wu, Tufts University (United States)

Yicong Zhou, University of Macau (Macau, China)

\section{Session Chairs}

1 Audio-Visual Human Identification

Sos S. Agaian, The University of Texas at San Antonio (United States)

Stephen P. DelMarco, BAE Systems (United States)

2 Image Segmentation in Applications

Stephen P. DelMarco, BAE Systems (United States)

Sabah Jassim, The University of Buckingham (United Kingdom)

3 Event and Visual Objects Detection

Sos S. Agaian, The University of Texas at San Antonio (United States)

Sabah Jassim, The University of Buckingham (United Kingdom)

4 Privacy and Security of Multimedia Objects

Sos S. Agaian, The University of Texas at San Antonio (United States)

Sabah Jassim, The University of Buckingham (United Kingdom) 